\title{
Preparation and Characterization of Hybrid Molecularly Imprinted Polymer Membranes for the Determination of Citrinin in Rice
}

(Penyediaan dan Pencirian Membran Hibrid Polimer Molekul Teraan untuk Penentuan Sitrinin pada Beras)

\author{
TIEN PING LEE*, BAHRUDDIN SAAD, LISA NAKAJIMA\& TAKAOMI KOBAYASHI
}

\begin{abstract}
A new method for the determination of Citrinin (CIT) in rice samples by hybrid molecularly imprinted polymer (MIP) membrane prior to its quantification by high performance liquid chromatography with fluorescence detection (HPLC-FD) is described for the first time. Conventional extraction methods, such as liquid-liquid extraction (LLE) and solid phase extraction (SPE) produce large volumes of environmentally hazardous waste and the common sorbents used in SPE often suffered from low selectivity. Hybrid MIP membranes offer the advantage of combining the mechanical integrity of the support membrane and the selectivity of the imprinted polymer. These membranes offer large specific surfaces, providing relatively high imprinting sites per unit mass, and fine porous structures, resulting in accessibility of imprinting sites. Thus, MIPS for CIT with 1-naphthol as mimic template were prepared using divinylbenzene as crosslinker and naphthol methacrylate was hybridized into the polyethersulfone scaffold by phase inversion process. The prepared hybrid MIP membrane was characterized using Fourier transform infrared spectroscopy (FTIR) and scanning electron microscopy (SEM). Using the resultant hybrid MIP membranes as sample preparation for HPLC-FD of CIT, detection and quantification limits of $0.5 \mathrm{ng} \mathrm{g}^{-1}$ and $1.7 \mathrm{ng}^{-1}$, respectively, were obtained. The intra-day and inter-day precision expressed in \%RSD ranged from 1.9-2.9\% and 2.6-5.9\%, respectively. The recoveries of CIT in rice spiked at 5, 25 and $100 \mathrm{ng}^{-1}$ ranged from 89.7-94.2\%. Thus, the hybrid MIP membranes can be valuable material for the practical determination of CIT in rice extracts.
\end{abstract}

Keywords: Citrinin; high performance liquid chromatography; hybrid molecularly imprinted membrane; rice

\section{ABSTRAK}

Kaedah baru untuk penentuan sitrinin (CIT) dalam sampel beras oleh membran hibrid polimer molekul teraan sebelum kuantifikasi oleh kromatografi cecair prestasi tinggi dengan pengesanan pendarflour dijelaskan buat kali pertama. Kaedah pengekstrakan konvensional, seperti pengekstrakan cecair-cecair (LLE) dan pengekstrakan fasa pepejal (SPE) menghasilkan sejumlah besar sisa berbahaya alam sekitar dengan penjerab biasa yang digunakan dalam SPE sering mengalami kepilihan yang rendah. Membran MIP hibrid menawarkan kelebihan menggabungkan integriti mekanikal membran sokongan dan pemilihan polimer teraan. Membran ini mempunyai permukaan khusus yang besar, menyediakan tapak teraan yang agak tinggi bagi setiap jisim unit dan struktur berliang yang halus, menyebabkan akses tapak teraan. Polimer molekul teraan (MIP) untuk CIT telah disediakan dengan 1-naftol (NA) sebagai templat tiruan. Seterusnya, membran hibrid polimer molekul teraan telah disediakan dengan memerangkap zarah MIP ke dalam perancah polietersulfon dengan menggunakan teknik fasa penyongsangan. Membran tersebut telah dicirikan dengan menggunakan transformasi Fourier spektroskopi inframerah (FTIR) dan mikroskopi pengimbasan elektron (SEM). Dengan menggunakan hibrid membran sebagai penyediaan sampel bagi analisis HPLC-FD untuk CIT, had pengesanan dan penentuan $0.5 \mathrm{ng}^{-1} \mathrm{dan} 1.7 \mathrm{ng} \mathrm{g}^{-1}$ telah tercapai. Ketepatan intra-hari dan antara hari yang dinyatakan dalam \% RSD masing-masing adalah antara 1.92.9\% dan 2.6-5.9\%. Perolehan semula CIT yang dipaku ke dalam beras pada 5, 25 dan $100 \mathrm{ng}^{-1}$ adalah 89.7-94.2\%. Oleh itu, membran hibrid MIP adalah bahan bernilai bagi penentuan praktikal CIT dalam ekstrak beras.

Kata kunci: Beras; kromatografi cecair prestasi tinggi; membran hibrid polimer molekul teraan; sitrinin

\section{INTRODUCTION}

Citrinin (CIT) (Figure 1a) a fungal metabolite produced by several fungal species of Aspergillus, Penicillium and Monascus, is one of the important mycotoxins that has been reported to contaminate rice, wheat, corn, barley and fruit juices (Čulig et al. 2017; Kiebooms et al. 2016; Pleadin et al. 2016). CIT is known to be nephrotoxic, hepatotoxic and carcinogenic to humans and animals. Kidney and liver are the major target organs. Together with ochratoxin A, these mycotoxins are suspected to be linked in human kidney disease, known as the Balken endemic nephropathy (Ali et al. 2016). The International Agency for Cancer Research (IARC) classified CIT in Group 3 despite limited evidence of its carcinogenicity to experimental animals and no evidence found in humans (Föllmann et al. 2014). Therefore, the presence of CIT in rice, a major staple food 
for people in Asian countries has become a major concern. Currently, the State Food and Drug Administration of China has issued advisory CIT limit of $50 \mu \mathrm{g} \mathrm{kg}^{-1}$ in red yeast rice-based food while the European Union recently recommended a maximum permissible limit of $2000 \mu \mathrm{g}$ $\mathrm{kg}^{-1}$ in food supplements based on rice fermented with the red yeast Monascus purpureus (Commission Regulation (EU) 2014). China has enforced the limit on CIT for functional food products to be less than $50 \mu \mathrm{g} \mathrm{kg}^{-1}$ while in Japan, the advisory CIT concentration limit in red yeast rice was $200 \mu \mathrm{g} \mathrm{kg}^{-1}$ (Urraca et al. 2016).

$\mathrm{Xu}$ et al. (2006) has reviewed the qualitative and quantitative analytical methods for CIT. Several methods for the determination of CIT in food, including colorimetric, immunochemical and chromatographic techniques have been reported (Yirga et al. 2017). Colorimetric techniques based on the natural fluorescence of CIT are disadvantaged due to the low recoveries and the lack of sensitivity. Immunochemical techniques such as enzyme linked immunosorbent assays and electrochemical immunosensor have been developed as rapid screening method for the presence of mycotoxins. These methods, although are highly specific as they are based on antibody-antigen interactions, but the cross-reactivity with structurally related compounds is common. To date, high performance liquid chromatography (HPLC) with fluorescence detection remains the most commonly used analytical method.

Sample preparation constitutes a very important step in chemical analysis. Its function is mainly to remove potentially interfering components present in the sample and as well as to preconcentrate the analytes in order to achieve the desired sensitivity. The most widely used method for the extraction and clean-up of CIT are liquidliquid extraction which involved chloroform as the extracting solvent. Alternatively, solid-phase extraction (SPE) that involved immunoaffinity columns (IACs) or aminopropyl SPE can be used (Hartl \& Stenzel 2007; Marley et al. 2016). These columns, however, are rather expensive, designed for single use and with the exception of IACs, lack selectivity. To increase selectivity, molecularly imprinted polymer (MIPs) has been introduced.

MIPs involve the formation of template-monomer complex with either covalent or non-covalent interactions, followed by copolymerization in the presence of a suitable cross-linker. After removing the template, imprinted cavities of specific size and shape were left inside the polymer network, exhibiting sites with molecular recognition properties for the target molecule. It is considered as an interesting alternative for clean-up, which contrary to IACs, do not suffer from storage limitations and stability problems when in contact with organic solvents. The highly cross-linked and three-dimensional network of MIPs is stable, robust and resistant to a wide range of $\mathrm{pH}$, solvents and temperature, exhibiting advantages of high selectivity, stability, reusability, easy and low cost of preparation (Martín-Esteban \& Sellergren 2012).

The high selectivity of MIPs has lent themselves as sorbents in SPE (MISPE). MISPE allows simultaneous and pre concentration of target analytes and clean-up extracts, removing undesirable sample matrix components. MISPES have been used for the determination of CIT in rice samples (Guo et al. 2010) and maize (Appell et al. 2015). The previous reported methods prepared MIP using the bulk polymerization, where the resulting polymer needs to be ground to obtain regular sized particles before loaded into the SPE cartridge. The process of crushing, grinding and sieving to obtain the appropriate particle sizes however, is tedious and time-consuming and often produces particles that are irregular in size and shape. Of more concern is the destruction of interaction sites during the grinding step. Since only a portion of the original polymer is used, this method uses high amount of the template. Template bleeding is also considered as one of the main drawbacks of MISPE. The difficulty in removing the entire template molecule, even after extensive washing is often encountered. The leakage of these trace amounts of the template remaining in the MIP is an obstacle in the accurate and precise assay of the target analyte (Sarafraz-Yazdi \& Razavi 2015; Vasapollo et al. 2011).

To overcome the disadvantages of traditional bulk polymerization, several alternative polymerization methods have been proposed. Precipitation polymerization represents a more practical approach as regular beads can be formed. This technique is easy, faster than the bulk polymerization method and provides regular beads in good yields (Tamayo et al. 2007). However, in one-step precipitate polymerization method, the binding sites are inside the network, the mass transfer of target molecules is very slow thus limits the effective binding sites of the target analytes (Yi et al. 2013). Core-shell MIPs particles prepared by multi-step precipitation polymerization was developed to address this issue (Son et al. 2011).

Investigations of hybrid MIP membranes have attracted significant interest in order to enhance the sensitivity and selectivity of MIPs. The preparation of hybrid MIP membranes using phase inversion technique demonstrated excellent membrane properties for binding and separation of template and their derivatives (Faizal et al. 2009; Takeda \& Kobayashi 2006; Yoshikawa et al. 2016). In this study, core-shell MIP particles were synthesized using 1-naphthol (NA) (Figure 1(b)) as the mimic template with two-step precipitation polymerization method and the hybrid MIP membranes were prepared using phase inversion technique for the extraction of CIT in rice samples. To the best of our knowledge, this work is the first to report on the development of hybrid MIP membrane for the extraction of CIT.

\section{EXPERIMENTAL DETAILS}

\section{CHEMICALS AND MATERIALS}

CIT $(\geq 98 \%)$ and sodium hydrogen carbonate was purchased from Sigma (St. Louis, MO, USA). Methanol and sodium hydroxide $(\mathrm{NaOH})$ were purchased from Wako Pure 
Chemical Industries (Osaka, Japan). NA and triethylamine and methacryloyl chloride were purchased from Tokyo Kasei Industry (Tokyo, Japan) and were used without further purification. Magnesium sulphate was purchased from Kanto Chemical (Tokyo, Japan). Tetrahydrofuran, chloroform, divinylbenzene (DVB), N-methyl-2pyrrolidone (NMP), acetone, azobisisobutyronitrile, HPLC grade acetonitrile, methacrylic acid, acetic acid, ethanol and dimethyl sulfoxide were purchased from Nacalai Tesque (Kyoto, Japan). The DVB was purified three times using silica gel column to remove inhibitor prior to use. Polyethersulfone (PES) was purchased from BASF (Ludwigshafen, Germany).

\section{PREPARATION OF NA MONOMER (NAM)}

NAM was synthesized following the procedure described earlier (Faizal et al. 2008). Briefly, to a $200 \mathrm{~mL}$ flask, NA (20 mmol) was added in tetrahydrofuran solution $(50 \mathrm{~mL})$ and the mixture was slowly stirred and cooled to $0^{\circ} \mathrm{C}$. Triethylamine $(40 \mathrm{mmol})$ and methacryloyl chloride (40 mmol) were added slowly to the solution. After stirring for $24 \mathrm{~h}$ at room temperature, the triethylamine salt was removed by filtration and the tetrahydrofuran solution was concentrated by evaporation. Chloroform $(60 \mathrm{~mL})$ was added and the solution was washed with water $(8 \times$ $50 \mathrm{~mL}$ ) in order to remove the salts. The chloroform layer was dried with magnesium sulphate and the solution was further concentrated and then evacuated under vacuum.

\section{PREPARATION OF CORE-SHELL MIP PARTICLES}

DVB (50 mmol) and azobisisobutyronitrile ( $1 \mathrm{mmol})$ were dissolved in $100 \mathrm{~mL}$ of acetone:water (122:28, v/v) and poured into a $300 \mathrm{~mL}$ three neck, round bottom flask. The flask was kept in an oil-bath and the stirring speed was kept at $300 \mathrm{rpm}$. After purging the nitrogen gas for 30 min, the temperature of the mixture was increased to $65^{\circ} \mathrm{C}$ under continuous introduction of nitrogen gas. After $2 \mathrm{~h}$,
NAM (10 mmol, prepared in section 2.2) which has been dissolved in $50 \mathrm{~mL}$ acetone: water ( 122:28, v/v) was slowly dripped into the mixture. The polymerization was carried out for $24 \mathrm{~h}$. After the polymerization was completed, the white precipitate formed was filtered and washed with acetone:water mixture thrice before being dried in a vacuum oven. The dried polymer (P(NAM-Co-DVB)) was hydrolyzed with $1 \mathrm{M}$ of sodium hydroxide solution at $60^{\circ} \mathrm{C}$ for $12 \mathrm{~h}$, filtered, washed with water until neutral and dried in vacuum oven again (Figure 1(c)). A non-imprinted polymer (NIP) was prepared using the same method of the copolymers and the terpolymers when no NAM was added to the polymerization mixture.

\section{PREPARATION OF HYBRID MIP MEMBRANE}

To prepare hybrid MIP membranes, the resultant core-shell MIP particles were mixed with $20 \%$ PES in NMP solution (2 $\mathrm{g}$ of PES in $8 \mathrm{~g}$ of NMP). The contents of the powders in the polymer solution were $10 \mathrm{wt} . \%$ to the scaffold polymer in the solution; $1 \mathrm{~g}$ of MIP into $20 \%$ PES in NMP solution. The mixture was stirred at $50^{\circ} \mathrm{C}$ for $12 \mathrm{~h}$. The obtained viscous solution was casted on the surface of a glass plate (150 $\mathrm{mm} \times 200 \mathrm{~mm})$ at $50^{\circ} \mathrm{C}$. The thickness of the membrane was controlled at $100 \mu \mathrm{m}$ using a polyester-film spacer (Lumirror, Japan). The casted solution was coagulated immediately in water at $25^{\circ} \mathrm{C}$ and kept for $12 \mathrm{~h}$ to solidify the membrane. The obtained membrane was then washed with excess of water to remove the NMP solution.

\section{CHARACTERIZATION OF CORE-SHELL MIP PARTICLES AND HYBRID MIP MEMBRANE}

The core-shell MIP particles were characterized using scanning electronic microscope (SEM) (JSM-5310LVB; JEOL, Japan) and confirmed by laser diffraction particle size analyzer (SALD7000; Shimadzu Corp., Japan). Fourier transform infrared (FT-IR) spectra were recorded for both MIP particles and hybrid MIP membrane using (a)

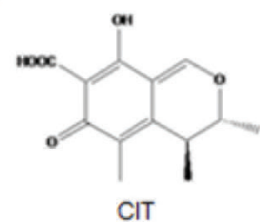

(b)

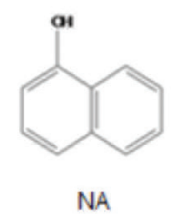

NA (c)

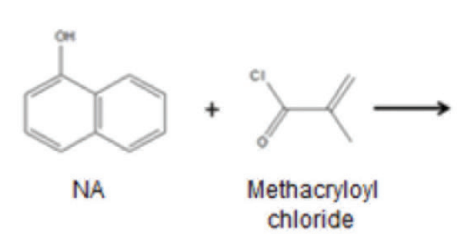

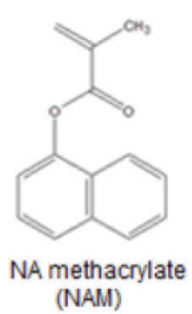
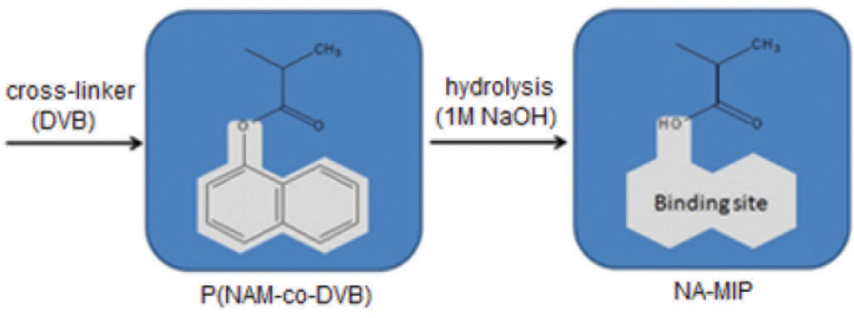

NA-MIP

FIGURE 1. Chemical structure of (a) CIT, (b) NA and (c) formation of binding site using NA as mimic template 
IR Prestige-21 FT-IR 8400s; Shimadzu Corp., Japan with $\mathrm{KBr}$ pellet technique (KBr: sample ratio 200: 1). For the membrane cross section, the membranes were placed in liquid nitrogen and were broken before pasting on a sample holder. After the gold coating, the SEM images were captured with the accelerating voltage set at $15 \mathrm{kV}$ at magnification of 500 times and 7,500 times, respectively.

\section{STANDARD CIT SOLUTIONS}

Stock solution of CIT (5000 $\left.\mu \mathrm{g} \mathrm{mL}^{-1}\right)$ was prepared by dissolving the solid standard in methanol and stored at $-18^{\circ} \mathrm{C}$ and protected from light. Standard solutions were prepared from appropriate dilutions of the stock solution with methanol:water $(80: 20, \mathrm{v} / \mathrm{v})$.

\section{BATCH BINDING OF CIT TO MIP AND NIP PARTICLES}

An aliquot $(40 \mathrm{~mL})$ of the sample solution was added to a sample vial $(50 \mathrm{~mL})$ and $0.05 \mathrm{~g}$ of MIP or NIP was dispersed. The initial solution concentration was $50 \mu \mathrm{M}$ of mixture (CIT and NA) and 20-100 $\mu \mathrm{M}$ of CIT. The solution was shaken at $30^{\circ} \mathrm{C}$ for $24 \mathrm{~h}$. The binding amount $[\mathrm{S}](\mu \mathrm{mol} / \mathrm{g})$ was calculated using:

$$
[\mathrm{S}]=(\mathrm{Co}-\mathrm{Ct}) \mathrm{V} / \mathrm{W}
$$

where $\mathrm{Co}$ and $\mathrm{Ct}$ represent the molar concentrations of the compounds that were measured before and after the binding process $(24 \mathrm{~h})$, respectively. $\mathrm{V}$ represents the solution volume and $\mathrm{W}$ is the mass of the imprinted polymer.

\section{EXTRACTION OF CIT WITH HYBRID MIP MEMBRANE}

For hybrid MIP membrane operation, $50 \mathrm{~mL}$ volume ultrafiltration cell (UF-8050; Amicon Inc.) was used. 25 $\mathrm{mL}$ of the aqueous solution ( $\mathrm{pH}$ adjusted to $4.0 \mathrm{using}$ $1 \mathrm{M} \mathrm{HCl}$ ) was introduced into the cell and the solution was permeated through the membrane under atmospheric pressure. After the permeation, the membrane was removed, dried with lint-free tissue and placed in a $10 \mathrm{~mL}$ vial. $10 \mathrm{~mL}$ methanol:acetic acid (98:2, v/v) was added and the analytes were desorbed by ultrasonication for 10 min. After desorption, the membrane was removed from the desorption vial and the extract was injected directly into the HPLC for analysis.

\section{REAL SAMPLE}

Blank rice sample (10 g) was weighed into a conical flask $(250 \mathrm{~mL})$ and was fortified with CTN working solution to achieve different concentration levels and were left in the fume cupboard overnight. $100 \mathrm{~mL}$ of $1 \%$ sodium hydrogen carbonate solution was then added. The suspension was shaken at $200 \mathrm{rpm}$ for $30 \mathrm{~min}$ and passed through a Whatman No. 4 paper filter. The $\mathrm{pH}$ for $20 \mathrm{~mL}$ of the filtrate was adjusted to 4.0 by using $1.0 \mathrm{M}$ $\mathrm{HCl}$ before performing the extraction procedure (Refer to Standard CIT solutions).

\section{HPLC CONDITIONS}

A HPLC system (CCPS; Tosoh Corp., Tokyo, Japan) equipped with fluorescence detector (RF-10AXL; Shimadzu Corp., Japan) was used. The separation was performed on Poroshell 120 EC-C18 analytical column $(100 \mathrm{~mm} \times 4.6$ $\mathrm{mm} \times 2.7 \mu \mathrm{m})($ Agilent Technologies, Wilmington, DE, USA) operated at $30^{\circ} \mathrm{C}$. The mobile phase consisted of acetonitrile, water, and acetic acid $(33: 66: 1, \mathrm{v} / \mathrm{v})$ with the flow rate of $1.0 \mathrm{~mL} \mathrm{~min}{ }^{-1}$. CIT exhibits natural fluorescence and the detector wavelengths were set at excitation and emission wavelength of $333 \mathrm{~nm}$ and $460 \mathrm{~nm}$, respectively.

\section{RESULTS AND DISCUSSION}

Mimic templates were usually selected when synthesizing mycotoxin MIPs due to its high toxicity and high cost. They interact with the functional monomer in a similar manner as CIT and is an inexpensive and safer alternative for imprinting polymers (Appell et al. 2015). In this study, NA which is similar to CIT, was selected as the mimic template (Figure 1). The MIP particles were formed by the copolymerization of NA with DVB as crosslinker. In this method, NAM addition was delayed for $2 \mathrm{~h}$ after the polymerization of DVB started in order to create the imprinted polymer shell on the surface of DVB seeds. Hybrid MIP membrane were then prepared by embedding the core-shell MIP particles into the polyethersulfone scaffold using phase inversion technique. The effect of extraction and desorption conditions using the hybrid MIP membranes for the determination of CIT in rice were studied.

\section{CHARACTERIZATION OF CORE-SHELL MIP PARTICLES}

Figure 2 portrays the relative size distribution of resultant spheres in acetone/water medium. With the increase of the polymerization time from 0.5 to $2 \mathrm{~h}$, the size distribution of the $\mathrm{P}$ (DVB) was changed from $0.2-0.5 \mathrm{~mm}$ to $200-800 \mathrm{~mm}$. After the copolymerization of $\mathrm{P}(\mathrm{NAM})$ was then carried out at $2 \mathrm{~h}$ in the $\mathrm{P}(\mathrm{DVB})$, the $\mathrm{P}(\mathrm{NAM}-\mathrm{CO}-\mathrm{DVB})$ had an average size distribution in $100-400 \mathrm{~mm}$. The SEM picture of the $\mathrm{P}$ (NAM-CO-DVB) was inserted in Figure 2. This presented that the particle size was in the range of $0.2-0.5 \mathrm{~mm}$, meaning that the light scattering results were observed in aggregated distribution of the particles in water medium.

The resultant copolymer particles were analyzed by FT-IR. In Figure 3, it was clear that the stretching band of $\mathrm{C}=\mathrm{O}$ group on NAM at $1749 \mathrm{~cm}^{-1}$ and the DVB band at 700 $\mathrm{cm}^{-1}$ can be found in the copolymer. After the hydrolysis process, the $\mathrm{OH}$ band intensity at $3500 \mathrm{~cm}^{-1}$ increased significantly, indicating the formation of $\mathrm{COOH}$ group in the copolymer.

\section{BATCH BINDING EXPERIMENT}

Batch binding experiments were performed to observe the selective recognition of the resultant MIP particles towards the template (NA) and CIT. These systems would expect 


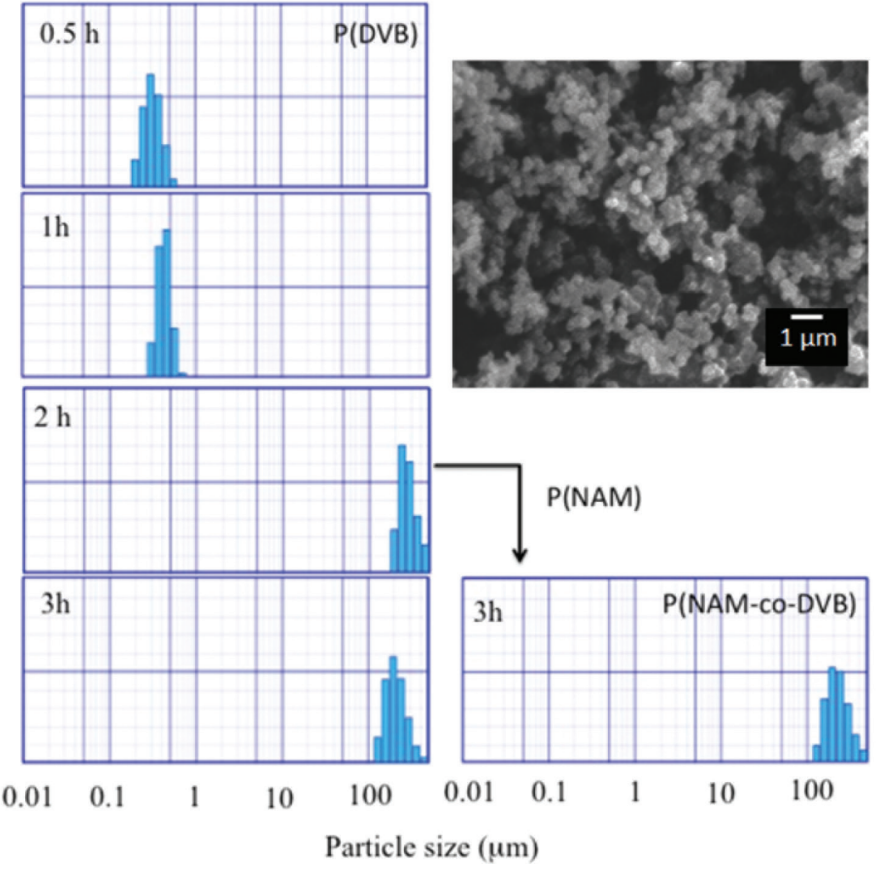

FIGURE 2. The relative size distribution of resultant spheres in acetone/water medium with the polymerization time from 0.5 to $2 \mathrm{~h}$ with the corresponding SEM micrograph

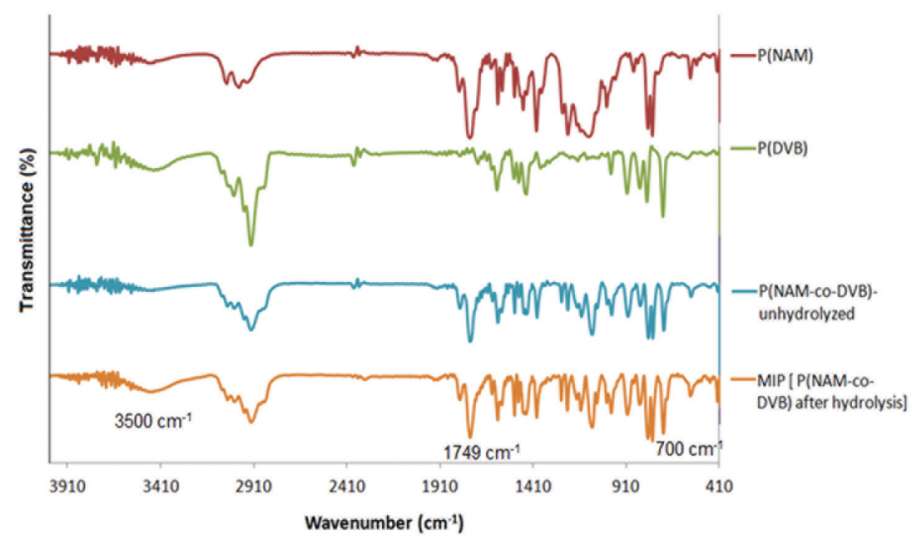

FIGURE 3. FTIR spectra for MIP particles prepared using NAM

as mimic imprinting to CIT. The MIP showed selective adsorption of NA, and CIT compared to the NIP, indicating that the mimic templates was successfully selected (Figure 4(a)). No significant binding of CIT and NA was observed on the NIPs. The selectivity for different concentrations of CIT towards the particles is shown in Figure 4(b).

\section{CHARACTERIZATION OF HYBRID MIP MEMBRANE}

The core-shell MIP particles were used for the preparation of hybrid MIP membrane. The scaffold PES was dissolved in NMP solution. PES and MIP particles are water insoluble. Therefore, after placing into the water bath, the PES with MIP particles will solidify to form membranes by phase inversion. Through the membrane formation, the scaffold polymer solution containing MIP will invert into the solid porous membrane (Takeda et al. 2007).
Figure 5 presents the SEM images of the MIP, cross section of the resultant hybrid MIP membrane and the PES membrane. As shown in the figure, the membranes contained sponge-like pores, showing typical membranes prepared by the phase inversion method. The resultant membrane thickness was about $175 \mu \mathrm{m}$ for the PES membrane with pore diameter from 12.5-37.5 $\mu \mathrm{m}$. The membrane thickness of hybrid MIP membrane (Figure 5(b)) was about $90 \mu \mathrm{m}$. The presence of particles with diameter in the range of 0.2-0.5 $\mu \mathrm{m}$ in the membrane wall was observed. This suggested that the hybridization was successful as the MIP particles were embedded in the pores of the PES scaffold as shown in Figure 4(d).

FT-IR spectra of the PES scaffold, the MIP spheres and the hybrid MIP membranes were obtained to confirm the presence of the MIP in the hybrid MIP membrane (Figure 5(e)). It was found that in the hybrid MIP membrane spectra, 

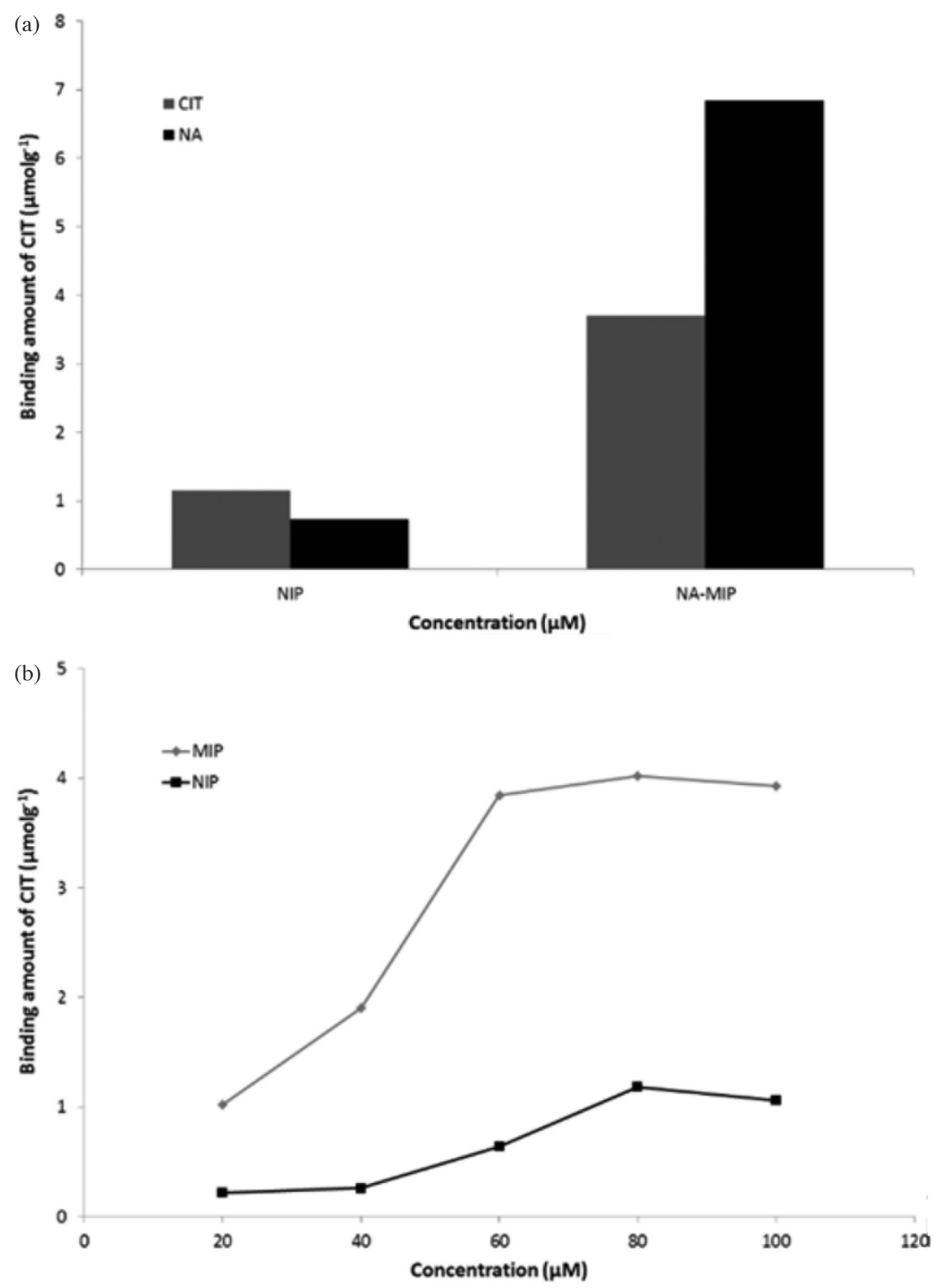

FIGURE 4. Batch binding experiment using MIPs and NIP with (a) mixture solution of CIT and NA and (b) with different concentrations of CIT

the stretching band of $\mathrm{C}=\mathrm{O}$ group near $1749 \mathrm{~cm}^{-1}$ which represented MIP spheres, and the asymmetric stretching bands of $>\mathrm{S}(=\mathrm{O})_{2}$ group near 1325 and $1299 \mathrm{~cm}^{-1}$ due to the PES scaffold were found. This indicates that the MIP spheres were hybridized successfully in the PES scaffold membrane.

\section{OPTIMIZATION OF CIT EXTRACTION ABILITY OF HYBRID MIP MEMBRANES}

Several extraction conditions were investigated to evaluate the different factors that affect the extraction ability of CIT on hybrid MIP membranes. Optimization was carried out by triplicate analysis with $100 \mathrm{ng} \mathrm{mL}^{-1} \mathrm{CIT}$.
Effect of MIP content The influence of MIP content in the hybrid MIP membrane for the extraction of CIT was investigated. The loading contents of the MIP particles in the hybrid MIP membrane were varied from $0-10 \mathrm{wt}$ \% in the 20 wt. $\%$ of PES. It was found that the PES membrane without the MIP particles showed binding ability of $30 \mathrm{ng}$ $\mathrm{mL}^{-1}$. As expected, when the loading content of the MIP particles increased, the binding ability of the membranes increased. The maximum binding ability was achieved when 10 wt. $\%$ of MIP was loaded.

Effect of $p H$ CIT is a weak acid, with pKa values of 3.55 for the acidic group and 4.8 for the basic groups. Therefore, 
(a)

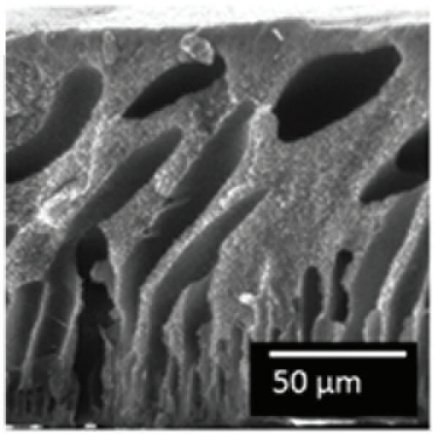

(c)

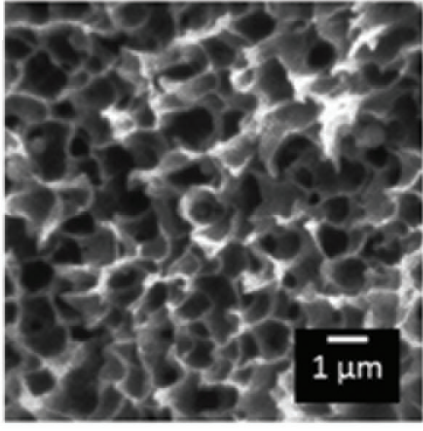

(b)

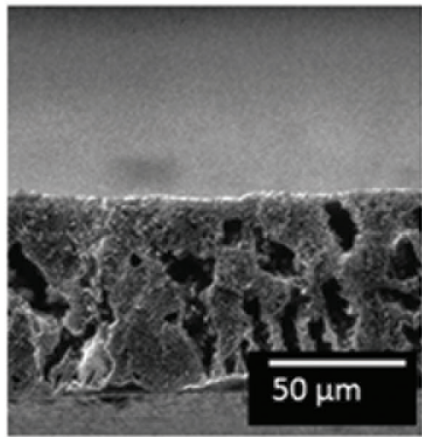

(d)

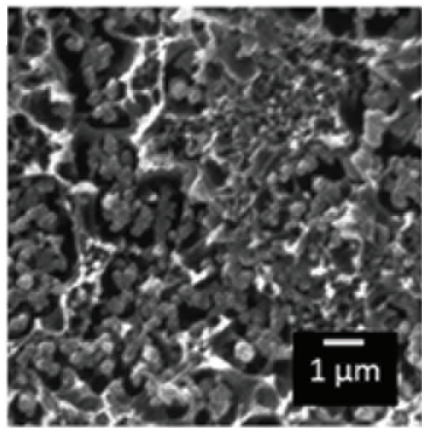

(e)

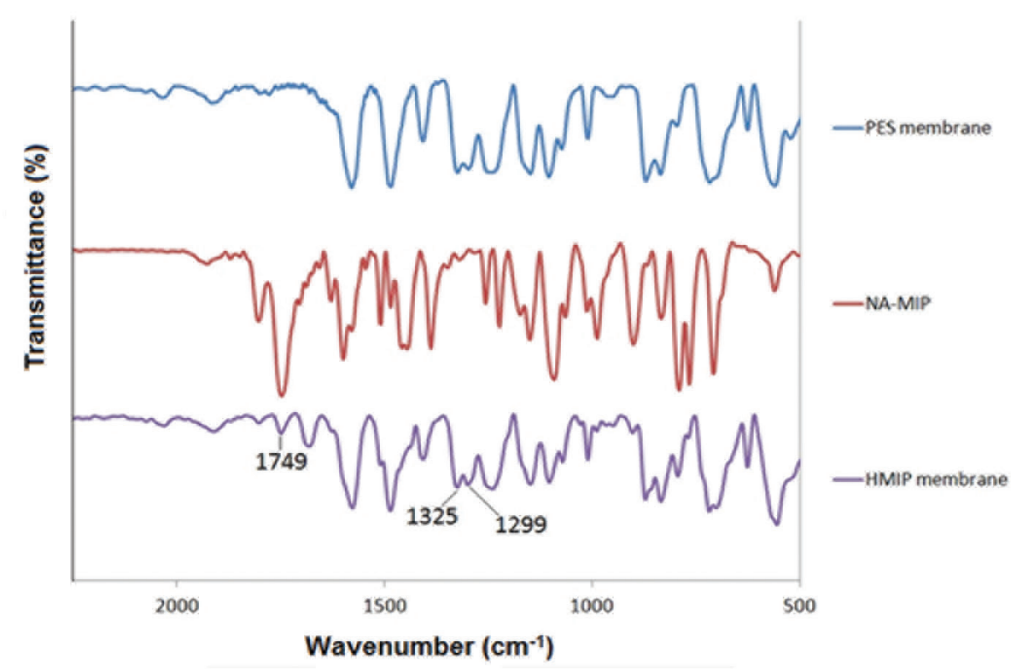

FIGURE 5. (a) SEM microgram of PES membrane, (b) SEM microgram of hybrid MIP membrane at magnification of 500 times, (c) SEM microgram of PES membrane and (d) SEM microgram of hybrid MIP membrane at magnification of 7,500 times, and (e) FT-IR spectra of PES, MIP and hybrid MIP membranes

the $\mathrm{pH}$ of the sample solution should be adjusted to be acidic to promote its extraction, as under neutral and alkaline conditions it is present predominantly in the dissociated form, which cannot be extracted. The $\mathrm{pH}$ of the sample solutions was varied from $1-5$ by the addition of hydrochloric acid (1.0 M). It was found that the optimum $\mathrm{pH}$ for CIT extraction was $\mathrm{pH} 4.0$. The influence of sample volume (10-30 $\mathrm{mL}$ ) was also investigated. When more than $25 \mathrm{~mL}$ of sample was fed, no additional enhancement of peak area was observed. Thus, $25 \mathrm{~mL}$ of sample was used in all experiments.
Effect of desorption solvent and time After binding, CIT was desorbed in $10 \mathrm{~mL}$ of organic solvents via ultrasonication. Various organic solvents (e.g. methanol, acetonitrile, methanol:acetic acid $(98: 2 \mathrm{v} / \mathrm{v})$ and acetonitrile:acetic acid $(98: 2 \mathrm{v} / \mathrm{v}))$ were tested. Methanol:acetic acid $(98: 2 \mathrm{v} / \mathrm{v})$ was found to be the best desorption solvent as the highest peak areas were obtained, followed by acetonitrile.

The desorption (ultrasonication) time was investigated between 3-15 min with $10 \mathrm{~mL}$ of methanol:acetic acid $(98: 2 \mathrm{v} / \mathrm{v})$. Longer desorption time gave higher peak area. However, there is no increase in peak area after $10 \mathrm{~min}$. Thus, 10 min was selected. 
Adopted extraction conditions The adopted conditions were: 10 wt. \% of MIP embedded in 20 wt. \% PES; pH4.0; sample volume, $25 \mathrm{~mL}$; desorption solvent, methanol:acetic acid (98:2 v/v); desorption time, $10 \mathrm{~min}$.

\section{METHOD VALIDATION}

Under the optimized binding conditions, matrix matched calibrations were done by spiking known amount of CIT into rice sample that were originally free from CIT. This approach enables the assessment of possible matrix effects to be evaluated. Linear range for rice was 2.5-250 $\mathrm{ng} \mathrm{g}^{-1}$. For each level, three replicate extractions were performed. The regression equations and correlation of determination were $\mathrm{y}=1908.2 \mathrm{x}+3298.5$ and $\mathrm{r}^{2}=$ 0.9984 , respectively. The limit of detection (LOD) and limit of quantification (LOQ) were determined according to the equations:

$$
\begin{aligned}
& \mathrm{LOD}=3.3 \mathrm{sa} / b, \\
& \mathrm{LOQ}=10 \mathrm{sa} / b
\end{aligned}
$$

where $s_{a}$ is the standard deviation of the intercept and $b$ is the slope of the regression line obtained from the calibration graph. The LOD and LOQ were 0.5 and 1.7 $\mathrm{ng} \mathrm{g}^{-1}$, respectively, suggesting that the method possess sufficient sensitivity for the analysis of citrinin in rice.
Recovery studies were carried out by spiking CIT to the non-contaminated rice and at different concentrations, i.e. 5,25 and $100 \mathrm{ng} \mathrm{g}^{-1}$. Three replicate samples were studied at each concentration. Good recoveries were obtained for all samples, ranging from 89.7-94.2\%. Figure 6 shows the chromatogram of the extracts from the blank and the spiked rice samples.

Intra-day precision (repeatability) was estimated at three concentration levels of CIT that were spiked to the samples. Inter-day precision (reproducibility) was performed by spiking to the matrix with three concentration levels of CIT and all samples were analyzed on three different days. Intra-day and inter-day precisions for peak areas, expressed as the percentage relative standard deviation (RSD), were 1.9-3.8\% and 2.6-5.9\%, respectively, indicating the good precision of the developed method.

Table 1 shows the important analytical characteristics of the present method when were compared with the previous reported methods. It is clear that analytical performance of the present method is comparable to those provided by other MIP-based or more conventional methods. On the other hand, the hybrid MIP membranes have the advantages of high capacity to bind the target molecule in the matrix. This is due to large surface area, faster transport of substrate molecule and faster equilibrium of binding cavities. In addition, with these, low energy consumption, compactness, and ease of scaling up would be advantage. (a)

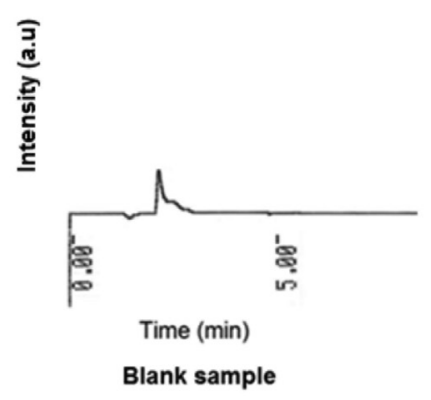

(b)

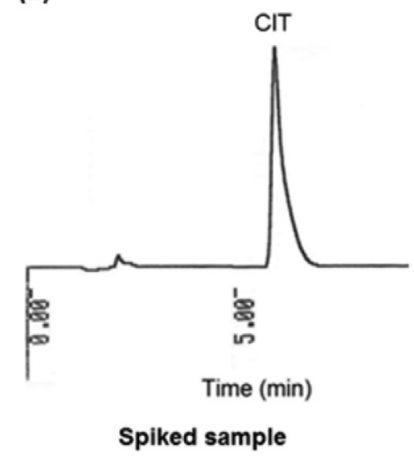

FIGURE 6. HPLC chromatogram of the extracts from (a) blank and

(b) rice sample spiked with $5 \mathrm{ng} \mathrm{g}^{-1}$ of CIT

TABLE 1. Comparison of the developed method with the previous study for the determination of CIT using MIP

\begin{tabular}{ccccc}
\hline Linear range & LOD & LOQ & Recovery (\%) & Reference \\
\hline $2.5-250 \mathrm{ng} \mathrm{g}^{-1}$ & $0.5 \mathrm{ng} \mathrm{g}^{-1}$ & $1.7 \mathrm{ng} \mathrm{g}^{-1}$ & $89.7-94.2$ & Current work \\
$1-15 \mu \mathrm{g} \mathrm{kg}^{-1}$ & $0.6-0.9 \mu \mathrm{g} \mathrm{kg}^{-1}$ & $1.7-3.3 \mu \mathrm{g} \mathrm{kg}^{-1}$ & $77-92 \%$ & Hartl \& Stenzel (2007) \\
$\begin{array}{c}\text { Wheat: } 10-200 \mu \mathrm{g} / \mathrm{kg}, \\
\text { red yeast rice }: 100-3000 \mu \mathrm{g} / \mathrm{kg}\end{array}$ & $3 \mu \mathrm{g} \mathrm{kg}^{-1}$ & $10 \mu \mathrm{g} \mathrm{kg}^{-1}$ & 80 to $110 \%$ & Marley et al. (2016) \\
$1.5-100 \mu \mathrm{g} \mathrm{kg}^{-1}$ & & & & \\
$10-3000 \mathrm{ng} \mathrm{g}^{-1}$ & $0.5 \mu \mathrm{g} \mathrm{kg}^{-1}$ & - & $86.7-97.7$ & Guo et al. (2010) \\
$5-200 \mu \mathrm{g} \mathrm{L}^{-1}$ & $0.01 \mu \mathrm{g} \mathrm{g}^{-1}$ & $0.03 \mu \mathrm{g} \mathrm{g}^{-1}$ & $82.3-91.5$ & Appell et al. (2015) \\
\hline
\end{tabular}

SPE; Solid phase extraction

MISPE; Molecularly imprinted solid phase extraction 


\section{CONCLUSION}

Core-shell MIP targeted for CIT using NA as mimic template were prepared using two-step precipitation method. Hybrid MIP membrane were then prepared by embedding the core-shell MIP particles into the polyethersulfone scaffold using phase inversion technique and was used in the determination of CIT in rice for the first time. High recoveries (89.7-94.2\%) and satisfactory precision (1.9$5.9 \%$ ) obtained suggest that the method can be a viable option for the analysis of CIT in food matrices.

\section{ACKNOWLEDGEMENTS}

This study was funded by Universiti Sains Malaysia (USM) Postgraduate Research Grant Schemes 1001/ PKIMIA/843052 and 1001/PKIMIA/811183. The authors would like to thank Dr. Nor Nadiah Mohamad Yusof and Mr.Zhao Yang for their comments and suggestions during the preparation of this work.

\section{REFERENCES}

Ali, N., Blaszkewicz, M., Alim, A., Hossain, K. \& Degen, G.H. 2016. Urinary biomarkers of ochratoxin A and citrinin exposure in two Bangladeshi cohorts: Follow-up study on regional and seasonal influences. Arch. Toxicol. 90(11): 2683-2697.

Appell, M., Jackson, M.A., Wang, L.C. \& Bosma, W.B. 2015. Determination of citrinin using molecularly imprinted solid phase extraction purification, HPLC separation, and fluorescence detection. J. Liq. Chromatogr. Relat. Technol. 38(20): 1815-1819.

Commission Regulation (EU). No 212/2014 of 6 March 2014 amending Regulation (EC) No 1881/2006 as regards maximum levels of the contaminant citrinin in food supplements based on rice fermented with red yeast Monascus purpureus. Off. J. Eur. Union L67: 3-4.

Čulig, B., Bevardi, M., Bošnir, J., Serdar, S., Lasić, D., Racz, A., Galić, A. \& Kuharić, Ž. 2017. Presence of citrinin in grains and its possible health effects. Afr. J. Tradit. Complement. Altern. Med. 14(3): 22-30.

Faizal, C.K.M., Hoshina, Y. \& Kobayashi, T. 2008. Scaffold membranes for selective adsorption of $\alpha$-tocopherol by phase inversion covalently imprinting technique. J. Membrane Sci. 322(2): 503-511.

Faizal, C.K.M., Kikuchi, Y. \& Kobayashi, T. 2009. Molecular imprinting targeted for $\alpha$-tocopherol by calix[4]resorcarenes derivative in membrane scaffold prepared by phase inversion. J. Membrane Sci. 334(1): 110-116.

Föllmann, W., Behm, C. \& Degen, G.H. 2014. Toxicity of the mycotoxin citrinin and its metabolite dihydrocitrinone and of mixtures of citrinin and ochratoxin A in vitro. Arch. Toxicol. 88(5): 1097-1107.

Guo, B.Y., Wang, S., Ren, B., Li, X., Qin, F. \& Li, J. 2010. Citrinin selective molecularly imprinted polymers for SPE. J. Sep. Sci.33(8): 1156-1160.

Hartl, A. \& Stenzel, W.R. 2007. Development of a method for the determination of citrinin in barley, rye and wheat by solid phase extraction on aminopropyl columns and HPLC-FLD. Mycotoxin Research 23(3): 127-131.
Kiebooms, J.A.L., Huybrechts, B., Thiry, C., Tangni, E.K. \& Callebaut, A. 2016. A quantitative UHPLC-MS/MS method for citrinin and ochratoxin A detection in food, feed and red yeast rice food supplem. World Mycotoxin J. 9(3): 343-352.

Marley, E., Brown, P., Leeman, D. \& Donnelly, C. 2016. Analysis of citrinin in cereals, red yeast rice dietary supplement, and animal feed by immunoaffinity column cleanup and lc with fluorescence detection. J. AOAC Int. 99(4): 1025-1031.

Martín-Esteban, A. \& Sellergren, B. 2012 . Molecularly imprinted polymers. In. Comprehensive Sampling and Sample Preparation, edited by Pawliszyn, J. Oxford: Academic Press. pp. 331-344.

Pleadin, J., Frece, J., Kudumija, N., Petrović, D., Vasilj, V., Zadravec, M., Škrivanko, M.,Perković, I. \& Markov, K. 2016. Citrinin in cereals and feedstuffs coming from Croatia and Bosnia \& Herzegovina. Food Addit. \& Contaminants: Part B Surveill. 9(4): 268-274.

Son, L.T. \& Takaomi, K. 2011. Hollow-fiber membrane absorbents embedded molecularly imprinted polymeric spheres for bisphenol A target. J. Membrane Sci. 384(1-2): 117-125.

Sarafraz-Yazdi,A. \& Razavi, N. 2015. Application of molecularlyimprinted polymers in solid-phase microextraction techniques. TrAC - Trends in Analytical Chemistry 73: 81-90.

Takeda, K. \& Kobayashi, T. 2006. Hybrid molecularly imprinted membranes for targeted bisphenol derivatives. J. Membrane Sci. 275(1-2): 61-69.

Tamayo,F.G., Turiel,E. \& Martín-Esteban,A. 2007. Molecularly imprinted polymers for solid-phase extraction and solid-phase microextraction: Recent developments and future trends. $J$. Chromatogr. A 1152(1): 32-40.

Urraca, J.L., Huertas-Pérez, J.F., Cazorla, G.A., Gracia-Mora, J., García-Campaña, A.M. \& Moreno-Bondi, M.C. 2016. Development of magnetic molecularly imprinted polymers for selective extraction: Determination of citrinin in rice samples by liquid chromatography with UV diode array detection. Anal. Bioanal. Chem. 408(11): 3033-3042.

Yoshikawa, M., Tharpa, K. \& Dima, S.O. 2016. Molecularly imprinted membranes: Past, present, and future. Chemical Reviews 116(19): 11500-11528.

Vasapollo, G., Sole, R.D., Mergola, L., Lazzoi, M.R., Scardino, A., Scorrano, S. \& Mele, G. 2011. Molecularly imprinted polymers: Present and future prospective. Int. J. Mol. Sci. 12(9): 5908-5945.

Xu, B.J., Jia, X.Q., Gu, L.J. \& Sung, C.K. 2006. Review on the qualitative and quantitative analysis of the mycotoxin citrinin. Food Control 17(4): 271-285.

Yi, L.X., Fang, R. \& Chen, G.H. 2013. Molecularly imprinted solid-phase extraction in the analysis of agrochemicals. $J$. Chromatogr. Sci. 51(7): 608-618.

Yirga, S.K., Ling, S., Yang, Y., Yuan, J. \& Wang, S. 2017. The preparation and identification of a monoclonal antibody against citrinin and the development of detection via indirect competitive ELISA. Toxins 9(3): 110.

Tien Ping Lee*

RCSI \& UCD Malaysia Campus

4 Jalan Sepoy Lines

10450 Pulau Pinang

Malaysia 
Bahruddin Saad

Fundamental and Applied Science Department

Universiti Teknologi PETRONAS

32610 Seri Iskandar, Perak Darul Ridzuan

Malaysia

Lisa Nakajima \& Takaomi Kobayashi

Department of Material Science and Technology

Nagaoka University of Technology

1603-1 Kamitomioka, Nagaoka

Niigata 940-2188

Japan
*Corresponding author; email: leetienping@rsciucd.edu.my

Received: 10 August 2018

Accepted: 7 May 2019 